\title{
Cervical Polyp
}

National Cancer Institute

\section{Source}

National Cancer Institute. Cervical Polyp. NCI Thesaurus. Code C2939.

A polyp that arises from the surface of the cervix. 